\title{
A Study of Child With Special Needs (CWSN) on Outcome Based Special Education
}

\author{
J. Komala Lakshmi \\ Academic Coordinator, Indira Gandhi College of Special Education, Kanuvai, Coimbatore, India \\ Corresponding author: jkchinmayav@gmail.com
}

Received: $10-12-2019$

Revised: $14-02-2020$

Accepted: 26-03-2020

\begin{abstract}
Educating every child is very essential, as they are the future citizens of a Country. A Child with Special Need (CWSN) may have a special educational need due to difficulty in learning. The outcome of educating the children with disability and learning difficulties with that of normal ones, represents the need for better developmental progress of CWSN. It reflects the need of special educators and paraprofessionals for CWSN. The paper aims at analyzing the CWSN and tabulated the different parameter associated with special education. The author designs a common standard KLMN SWASTIK MODEL to assist the special educators in bringing out their better proficiency for every CWSN and to the teachers of regular school as well. The proposed model gives positive directions in educating the CWSN for life by imparting to them basic life skills and possibilities for better outcome based on special education.
\end{abstract}

Keywords: KLMN swastik, CSWN, Special Education, Intellectual disability, Paraprofessional

Education helps people to see the world as a just and fair place where everyone is given equal opportunities. It is a must for a promising, self sufficient, secure future and a stable life. In India special education as a separate system of education for disabled children outside the mainstream education system evolved way back in 1880s. Consequent on the success of international experiments in placing children with disabilities in regular schools, the Planning Commission in 1971 included in its plan a programme for integrated education. The Government launched the Integrated Education for Disabled Children (IEDC) scheme in December 1974. It was a Centrally Sponsored Scheme aimed to provide educational opportunities to children with special needs (CWSN) in regular schools and to facilitate their achievement and retention. All the schools in the area are expected to enroll-children with disabilities. Training programs were also given to Special educators ${ }^{[1]}$.

Special Education: The term "Special Need Education" (SNE) has come into use as a replacement for the term "Special Education", as the older one was mainly understood to refer the education of all those children and youth whose needs arise from disabilities or learning difficulties. The Statement affirms: "those with special educational needs must have access to regular schools which should accommodate them within child centered pedagogy capable of meeting these needs" ${ }^{2[}$.

Special education therefore basically refers to "educational programs and practices designed for students- who are handicapped or gifted, with mental, physical or emotional disabilities and hence require special teaching approaches, equipment or care within or outside a regular classroom." Disabilities may be mental, physical, emotional and developmental. So, within its range special needs, includes a number of impairments, some of which are: Speech and Language Impairment, Autism spectrum Disorder, Multiple Disabilities, Traumatic Brain Injury, Visual Impairment (including blindness), Hearing Impairment, Developmental Delay, 
Emotional Disturbance, Specific Learning Disability, Orthopedic Impairment, Other Health Impairments, Developmental delay, Intellectual Disability ${ }^{[3]}$.

\section{Famous Indians With disabilities who inspire us every day}

These Indians with disabilities prove that it is just a state of mind. Learn about 16 amazing people who have not let their disability hold them back them in any way. From performing in international arenas to bagging gold medals in sports events, there is nothing these champions cannot do! They have made us so proud.

Sudhachandran- This Indian actress and classical dancer needs no introduction

Ravindra Jain- visually impaired, Jain started singing at a very young age and took his passion to a new high when he joined the Indian music industry, becoming one of the most notable music directors of the 1970s

Girish Sharma- He lost a leg in a train accident when he was a kid. But, this setback in life did not stop him from becoming a badminton champion

\section{Shekar Naik}

Naik is a perfect example of someone who has converted a disability into an opportunity. With his strong will power and dedication, he became a T20 Blind Cricket World Champion and has 32 centuries to his name

$\checkmark$ H Ramakrishnan was affected by polio in both his legs at a young age of two and half years. From being denied admission in a regular school to getting rejected for a job due to his disability, Ramakrishnan has had to struggle at each step in his life. In spite of this, he worked as a journalist for 40 years and is currently CEO of SS Music television channel. He is also a musician and has showcased his talent at various platforms. He runs a charitable trust called Krupa to help the specially-abled ${ }^{[4]}$.

\section{Outline Map of the Article}

The Review of Literature section Discusses about the Joint family institution in context with disabled child and behavioural management of disabled. The existing system section discusses about the special education and its significance, objectives and outcomes. The Proposed System discusses about the challenges, threats and need for special education and the key stages of desired outcome stages of special education. The conclusion Section discusses about the contribution expected from every other domain to educate the CWSN.

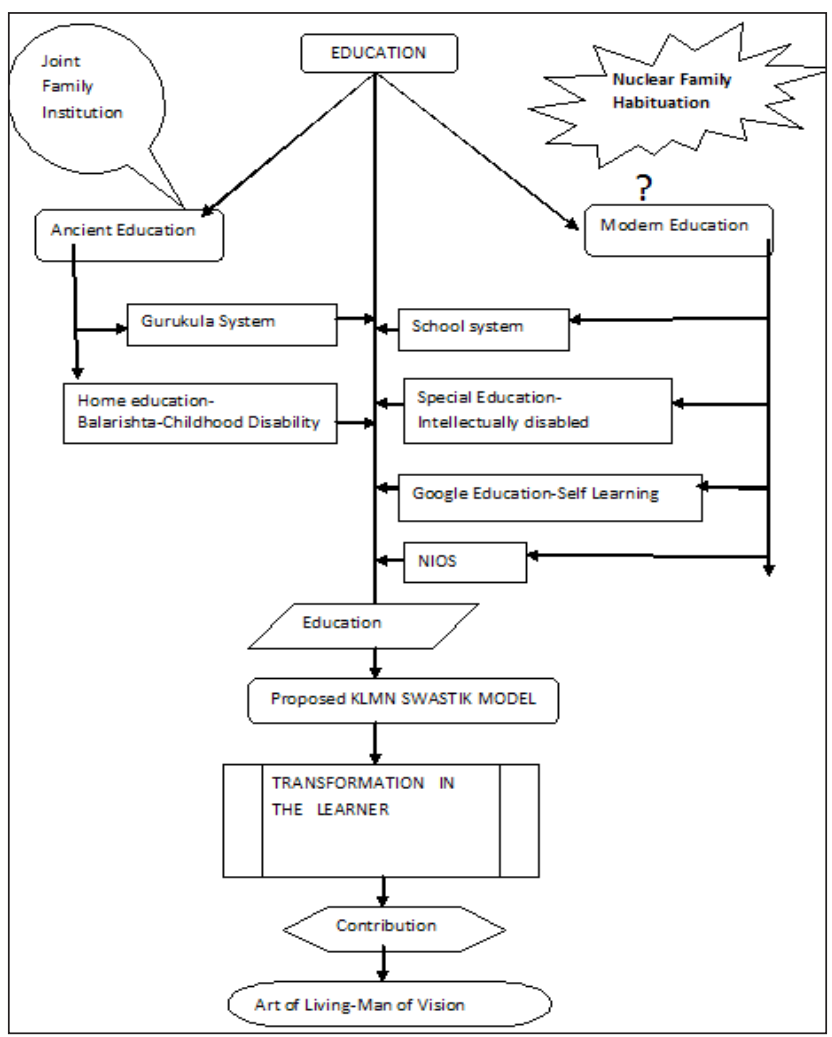

Fig. 1: Outline Map

\section{REVIEW OF LITERATURE}

The first part of this section discusses about working with families of children with disabilities in India. The second part discusses about the Behavioural Management of children with intellectual disabilities (ID) in today's Scenario.

\section{Working with Families of Children with Disabilities in India}

Understanding family structure in India is important in the context of delivering services to children with disabilities.

\section{Joint family is a great Institution System- 'vasudhaiva kutumbakam'}

$\odot$ The family, in Indian society, is an institution by itself and a typical symbol of the collectivist culture of India right from the 
ancient times. The joint family system or an extended family has been an important feature of Indian culture, till a blend of urbanisation and western influence, began to affect in home and hearth. This is especially true of urban areas, where nuclear families have become the order of the day. There is no denying the fact that socio-economic factors have played their role in the joint family system getting diluted.

$\odot$ A joint family or undivided family is an extended family arrangement prevalent throughout the Indian subcontinent, particularly in India, consisting of many generations living in the same household, all bound by the common relationship ${ }^{[5]}$.

$\odot$ If there is one cohesive, cementing force at the heart of traditional Indian society - a single, powerful strand which for centuries, has woven the tapestry of our rich, social fabric replete with diversity, into a wholeit is our family system ${ }^{[6]}$.

\section{$\square$ Relationships}

$\odot$ Different relationships are addressed via different names. The nature of relationship also varies. Relations can be of equivalence, mutual respect or teasing in nature. In joint families the relation is dictatorial in nature. The Head of the family decides everything about other members of the family. In joint families in northern and central India between a bride or sister-in-law and her younger brother-in-law, a joking or teasing relationship is common, and the relationship towards an older brother-in-law is that of respectfulness ${ }^{[7]}$.

\section{$\square$ Balarishta - Childhood Disability}

$\odot$ Indian Families believed that the (Intellectual disability (today's word)) ill-health during infancy and childhood than of any other kind of adversity that can strike a person at that age may be, by certain specific planetary situations or combinations or associations present at the time of one's birth or at the time of query or at a particular muhurta or happening as are revealed.

\section{Life Span of Disabled Child}

$\odot$ The determination of probable life-span be taken up in right earnest ${ }^{[8]}$. The life span is classified as:

1. death within one year,

2. death within 12 years,

3. death within 32 years,

4. death within 70 years,

5. death within 100 years and

6. death after 100 years $^{[9]}$.

\section{$\square$ Handling special Child At home}

$\odot$ The family's eldest and oldest person believed that there was no harm by the special child and all the family members have been groomed with compassion and love towards that special child. At every point of their life time some family member took charge for their entire life. The special child also cooperative and adaptable to their family members.

\section{$\square$ Education of special Child}

$\odot$ The gurukula education was not provided to such special child. Home education was done and the special child was able to take care of himself and do some outcome oriented task within his capability. Say for example, washing clothes, cows caring, cleaning the lands, any other jobs that do not need intellect like masculine activities and complementary education had been taught at home. Hence, the disabled child lived their life happily.

\section{Psychological significance of joint family system}

$\odot$ The strong bonding it creates among siblings and other members of the family even while providing a sense of security to the children.

$\odot$ Children who grow up in an extended family with grandparents, aunts, uncles and cousins will imbibe the qualities of sharing, caring, empathy and understanding.

$\odot$ Joint families has a positive impact on the emotional quotient of children.

$\odot$ Respect and care for elders. 
$\odot$ The fact that grandparents or other members like aunts will take care of children when both the parents are employed, immensely contribute towards making the childhood memorable and happier, a crucial factor to the overall personality development of an individual.

$\odot$ Creates a strong bond of unity at an early age, paves the way for social cohesion and in a broader sense promotes national unity

$\odot$ The qualities of sharing and caring by senior family members automatically lead them to think of a secure future for their children by making savings. This is in turn helps in strengthening national economy.

$\odot$ Family values play an important role in shaping the outlook of people.

\section{Imbibing Values}

$\odot$ Children who grow up in an extended family not only imbibe qualities of tolerance, patience, democratic attitude of accepting others' viewpoints, but also develop sportsman's spirit while playing with siblings and cousins.

$\odot$ The family system lays the seeds for social cohesion and democratic thinking.

$\odot$ Adopting our age-old philosophy of Vasudhaiva Kutumbakam, which embodies the spirit of humanism, compassion, magnanimity and tolerance, family becomes the basic building block of a harmonious, inclusive society. Family can shape the world view, foster and reinforce the value system of the individuals and therefore, consequently, be the warp and weft of a sustainable, peaceful, inclusive, prosperous world.

The family members' share of conflict situations, quarrels and misunderstandings results modern family system.

\section{Modern Education system}

Universal and compulsory education for all children in the age group of 6-14 was a cherished dream of the new government of the Republic of India. This is evident from the fact that it is incorporated as a directive policy in article 45 of the constitution.
But this objective remains far away even more than half a century later. However, in the recent past, the government appears to have taken a serious note of this lapse and has made primary education a Fundamental Right of every Indian citizen. The pressures of economic growth and the acute scarcity of skilled and trained manpower must certainly have played a role to make the government take such a step. The expenditure by the Government of India on school education in recent years comes to around $3 \%$ of the GDP, which is recognized to be very low.

\section{Modern family system}

The present-day lifestyle is causing serious damage to the critical role played by a joint or an extended family system in preserving cultural values, traditions and customs, which have been passed on from generation to generation. However, at the same time, we, Indians must consider ourselves to be better placed than others because the concept of 'Vasudhaiva Kutumbakam' (world is one family) is ingrained in our DNA. It is our duty to pass on the collective age-old wisdom to our succeeding generations.

\section{Women's emancipation}

Societies evolve with changing times and any process that brings in progressive customs and practices should be welcomed by one and all. For instance, emancipation of women through education is essential to break the shackles of regressive social problems like child marriages, dowry menace, violence against women and superstitious customs. Women should not only be empowered through education, but they should be encouraged to be in the forefront of the battle against blind beliefs and customs, even if there is resistance from male-dominated patriarchal societies. As has been very aptly said educating a woman amounts to educating an entire family and a society, which is the fundamental requirement for the growth and progress of a nation.

\section{Psychological transition in GIRL to transform as "MOTHER"}

Mothers around the world have been celebrated for their full-time duties to raise generations. Their roles in society have been impeccable regardless of 
the setting. The question about how mothers raise their children has been under public scrutiny and many continue to debate the outcome. In the long run there is no school of parenting. Every mother uses what suits them to bring about the best child and be the champion mother ${ }^{[10]}$.

\section{Ancient Mother}

The way mothers raise their children has changed recently with influences from the modern and Western ideology. However, raising a child in the olden days was different and traditional mothers made sure the package had it all. "We came from an era where your mother was your role model. You simply saw yourself through her and that was it. She taught you almost everything you needed to survive the world after and at the same time to be responsible. "As a mother, children are in their best state to shape when they are young and that is the time one really needs to be the right mother.

\section{Modern mother}

A mother, had to make the child understand why it is bad to do wrong and for them to realise the consequences. A mother has to make them understand this concept at a very young age because as they grow, life will not always forgive them. A mother . do not want her children to be corrected by the prisons, hospital and the mortuary."Being a mother is a full time duty and society will always point a finger to the mother if her offspring do not come out right.

\section{Significance of Modern Mother}

1. The modern mother is considered to be influenced by the book.

2. The modern mother is more of a teacher, distant from the child but equally influential.

3. Unlike traditional mothers, modern mothers are not always there for child. However does not take them away from motherly duties as they make ways to manoeuvre between the daily job and their responsibilities as a mother.

4. Regardless of the method mothers use to nurture their children, their role in society remains of paramount importance in determining the strength of generations to come. In many people's lives, their present living and desire to be whoever traces back to the backbone of their dreams- the mother.

\section{Behavioural Management of children with intellectual disabilities (ID) in today's Scenario}

Managing behavioral problems is a major concern in the comprehensive rehabilitation of people with ID. Children with ID that attend schools receive some form of behavioral management, irrespective of the nature of school (special or regular). In rural India, where the majority of children with ID do not attend school, there is no institutional support in place to help children with their behavioral problems.

In addition, the outreach activities performed by rehabilitation institutions in rural communities are poor. Insufficient awareness, misinformation, malpractice and social issues negatively affect the management of behavioral problems in children with ID in rural communities.

In the absence of institutional support, parents apply various methods of handling such behavioral problems. Three approaches are prominent in rural communities: First, parents often ignore the behavior. Second, they may offer the child something to eat or to play with. Finally, the third method involves punishing the child physically or verbally. According to the principles of behavior modification, children's undesired behaviors get stronger and more when behavior management involves inconsistent or inadequate reinforcement.

There is an unmet need for studies that focus on behavioral interventions for children with ID that live in low- and middle-income countries. For example, we do not yet know which ID benefit more from behavioral intervention or if there is any relationship between a child's intelligence quotient (IQ) (a child who has ID) and their behavioral improvement after an intervention.

The behavioral assessment scale for Indian children with mental retardation (BASIC-MR) was used to quantify the study subjects' behavioral problems before and after we applied behavioral management techniques (baseline and post-intervention, respectively). The baseline and post-intervention scores were analyzed using the following statistical techniques: Wilcoxon matched-pairs signed-rank 
test for the efficacy of intervention; $\chi^{2}$ for group differences ${ }^{[11]}$.

The outcome of this behavioral management study suggests that behavioral intervention can be effectively provided to children with ID in poor areas.

\section{EXISTING SPECIAL EDUCATION SYSTEM}

Historical Perspective: In India special education as a separate system of education for disabled children outside the mainstream education system evolved way back in 1880s. The first school for the deaf was set up in Bombay in 1883 and the first school for the blind at Amritsar in 1887. In 1947, the number of schools for blind increased to 32 , for the deaf 30 and for mentally retarded 3 .

\section{Mode of Special Education in Schools}

Children with disabilities are educated in India through special schools. There exist a few schools exclusively for blind and deaf under government sector. But there is not any special provision in mainstream government schools for education other disabled children like low vision, leprosy cured, hearing impaired, locomotory disabled, mentally retarded, mentally ill, autism affected, cerebral palsy affected and multiple-disabled. These children with disabilities are nurtured to some extent through the special schools of non-government sector.

The term "Special Need Education" (SNE) has come into use as a replacement for the term "Special Education", as older one was mainly understood to refer the education of all those children and youth whose needs arise from disabilities or learning difficulties. The Statement affirms: "those with special educational needs must have access to regular schools which should accommodate them within child cantered pedagogy capable of meeting these needs".

\section{SURVA SHIKSHA ABYAN framework}

Making schools barrier free to access for CWSN is incorporated in the SSA framework. 4.44 thousand Schools have ramps for CWSN. The play equipment can be designed depending on the child's abilities.

\section{Special education Teacher}

A Special Educator therefore has to have the following qualities: Organized; Patient; Intuitive; Creative; Detail oriented; Hard-working; Optimistic; Adaptable; Good sense of humour; A love for children; A love for teaching.

\section{Educational considerations}

A child with an intellectual disability can do well in school but is likely to need the individualized help that's available as special education and related services. The level of help and support that's needed will depend upon the degree of intellectual disability involved.

\section{General education}

Supplementary aids and services.

Adaptive skills.

Transition planning.

IDEA requires that, at the latest, transition planning for students with disabilities must begin no later than the first IEP to be in effect when they turn 16 . The IEP teams of many students with intellectual disabilities feel that it's important for these students to begin earlier than that. And they do.

\section{Modification for Students with Intellectual Disabilities}

Children with intellectual disabilities need some additional support and modifications in their environment, as well as in the type of activities they do. Here are a few modifications for students with an intellectual disability that will help them to learn better ${ }^{[12]}$.

\section{Quiet Work Space}

Functional Activities

Repetition of Concepts Over the Day

Teacher-Student Ratio

$\checkmark$ Hands-on Learning

Safety Measures

Schedule

\section{Signs of intellectual disability ${ }^{[13]}$}

Sit up, crawl, or walk later than other children; Learn to talk later, or have trouble speaking,

Find it hard to remember things,

Not understand how to pay for things,

$\square$ Have trouble understanding social rules, 
Have trouble seeing the consequences of their actions,

$\square$ Have trouble solving problems, and/or

$\square$ Have trouble thinking logically.

\section{Safety and security challenges}

Inside institutions in several countries, Human Rights Watch has documented that children with disabilities often face serious neglect and abuse, including beatings and psychological violence, sexual violence, involuntary and inappropriate medical treatment, use of abusive physical restraints, seclusion and sedation, denial of education and denial of regular contacts with families. These abuses can severely impede their physical, intellectual, emotional, and social development, and these harmful impacts are not limited to contexts in which the worst abuses take place.

Institutional care for children is also often characterized by physical, psychological, and sexual violence by staff and other children. Violence that children may experience in institutions is often long-term and can lead to severe developmental delays, various disabilities, irreversible psychological harm, and increased rates of suicide and criminal activity. Institutionalization also results in segregation of children with disabilities from their families and communities - sometimes for their entire lives. They are separated from their parents and siblings and not provided with opportunities to form attachments.

$\square$ Use of restraints and seclusion.

Children with disabilities living in institutions are often subjected to solitary confinement and prolonged use of restraints. Human Rights Watch documented that staff in many institutions in India, Indonesia, Greece, Russia, and Serbia frequently use physical and chemical restraints on children and confine children to cribs or caged beds.

$\square$ Denial of education.

Denial of regular contact with families ${ }^{[14]}$.

\section{PROPOSED SYSTEM}

The Proposed system is designed to meet the limits and challenges that the existing system dealt with.
This model suggests the outcome based on special education.

\section{Proposed KLMN SWASTIK MODEL}

The KLMN SWASTIK is an acronym where k-knowing; L-Learning; M-mind mapping; N-New idea Contributing to the nation building and people binding from the child's nurturing. The Special Education Logo is the standard education logo that suits for all type of education namely, Google Education-Self-Learning, CWSN, Regular school Education, Home Education, NIOS-National Institute of Open Schooling, Gurukula learning for Vedic studies, Technology equipped online Education, etc., The KLMN SWASTIK teaching learning mode ${ }^{[15]}$ for overall development of the child can be used as a teaching strategy for bringing change and transformation in the CWSN.

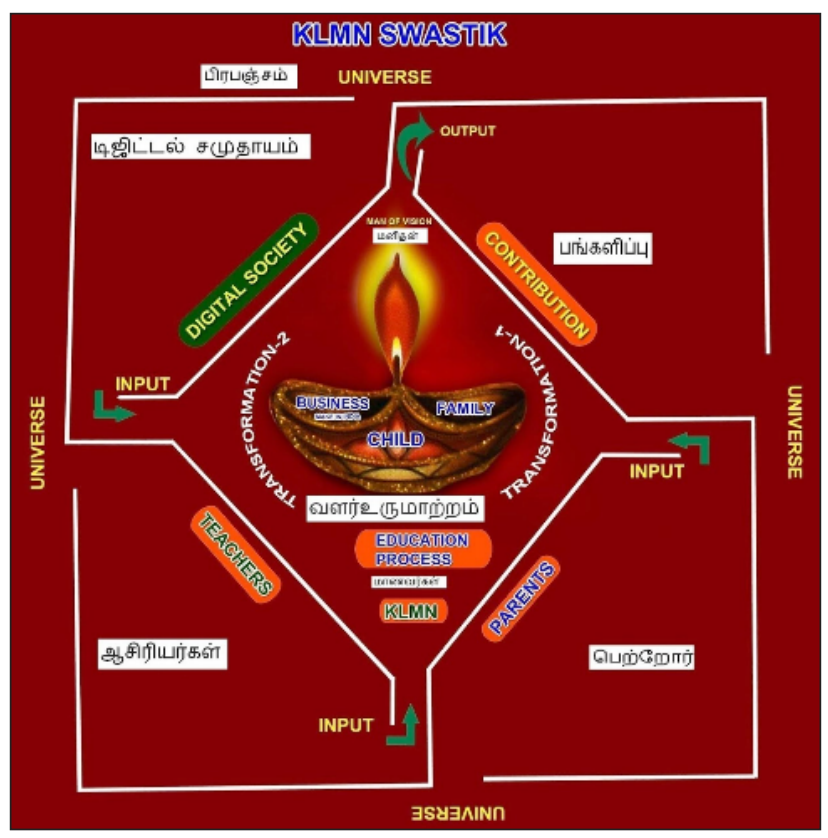

Fig. 2: (Special) Education Logo-KLMN SWASTIK

\section{Challenges Associated with CWSN to proposed KLMN MODEL}

$\square$ Do gender, age, population type, socioeconomic status, category of ID, interventional settings and associated conditions affect the outcome of behavioural intervention in children with ID?

$\square$ Does improvement take place across all domains of behavioural problems in children with ID who have received behavioural intervention?

Many people in the community believe that 
children with ID can transfer their disabilities to other children. Some of the children's behavioural problems may have resolved if they were placed in school.

$\square$ Frequent migration of families, sickness of participants, myths, misbeliefs, cultural practices, parental attitudes, parental cooperation and (to some extent) the language barrier between professionals and parents

Clinical approach to a behaviour disorder in a child with an intellectual disability

Sleep Disorders- Sleep deprivation in humans can have negative side effects including decreased alertness, mood changes (e.g., irritability, fatigue) and cognitive changes (e.g., short-term memory alteration). (e.g., nightwaking, night-settling, early waking).

\section{Agitation}

\section{Aggression}

Self Injury ${ }^{[16]}$.

In this $21^{\text {st }}$ century, the desired outcome of education ${ }^{[17]}$ is challenging in this digital parenting era.

The following parameters namely, Digital Society, Digital Parenting, Heart transformation, Intellectual Transformations, Social Distancing, Socio Economic are increasing.

The Digital Society includes all virtual friends who we can see speak only thorugh electronic machines. The Digital Parenting Refers to the issues faced by the parents in handling the psychological behaviour in children due to the impact of social media. The heart transformation is done thorugh the social organization called school, but when the school itself is transforming to use machines for education, the direct contact of teacher a human is missing in education. The heart oriented transformation is hard to groom.

The Intellectual Transformation is perfect and the best outcome is good human contributing best medicine, science and technology, socio-economic stability. The Outcome of education is the MAN OF VISION, qualified of contributing something or giving back something with gratitude to the nature, nation, people and humans of course all living beings.
Whereas in DOSE the outcome is also the same, the Man of Vision who could afford himself independently and belong to the heart transformation part of the KLMN SWASTIK. The students can help each other as it is challenging for them to contribute intellectually as compared with normal children.

Moreover, the heart and intellect transformation is expected to develop better outcome in both CWSN and normal child as well. The following Table depict the challenges faced by the special educator teacher in this digital era where the education is transformed to flipped classroom with smart phones.

The CWSN children found hard to use smart phones or gadgets for education. So school for CWSN is inevitable and high prioritised requirements of the parents.

Here in Special Education system, the key stage objectives designed by the proposed model comparatively with the desired outcomes of education for a normal child are as follows.

\section{Design of the key stage objectives of the Outcome of Special Education (DOSE)}

1. To increase the confidence of a number of special children to aspire for a valuable education like their normal peers.

2. To propose a set of nonbiased methods of evaluation for determining if a child has a disability. Testing and evaluation must not discriminate based on race, culture, or native language

3. To give rest and fellowship for parents and families through experiential learning through excursion

4. To organise events that encourages school spirit and orientation programme to know the services provided by the government.

5. To provide opportunities for families to talk together about common struggles.

6. To facilitate parents with low income with good medical care for their children especially for students with unique medical complications

7. To provide a gateway to parents to build a good relationship between newer and older parents. 
Table 1: Challenges for DOSE*

\begin{tabular}{|c|c|c|c|c|c|}
\hline S.No. & Level & $\begin{array}{l}\text { At the end of Primary School, } \\
\text { Pupils should:class 1-5 }\end{array}$ & $\begin{array}{l}\text { At the end of the middle } \\
\text { School, Students should:class6-8 }\end{array}$ & $\begin{array}{l}\text { At the end of the high } \\
\text { school, students should: }\end{array}$ & $\begin{array}{l}\text { At the end of higher secondary } \\
\text { school, students should: }\end{array}$ \\
\hline 1 & $\begin{array}{l}\text { Integrated } \\
\text { Development } \\
\text { P-Physical; }\end{array}$ & $\begin{array}{l}\text { Have strong understanding on } \\
\text { the working of senses and their } \\
\text { relations to mind and body }\end{array}$ & $\begin{array}{l}\text { Have strong understanding on } \\
\text { Physical grooming }\end{array}$ & $\begin{array}{l}\text { Have strong understanding } \\
\text { on Physical fitness }\end{array}$ & $\begin{array}{l}\text { Have strong understanding on } \\
\text { Health Education }\end{array}$ \\
\hline 2 & $\begin{array}{l}\text { Integrated } \\
\text { Development } \\
\text { M-mental; }\end{array}$ & $\begin{array}{l}\text { Understand the relation between } \\
\text { behaviour and environment }\end{array}$ & $\begin{array}{l}\text { Understand the link between } \\
\text { emotions and behaviour }\end{array}$ & $\begin{array}{l}\text { Understand the impact of } \\
\text { emotions and behaviour }\end{array}$ & Able to handle Emotions \\
\hline 3 & $\begin{array}{l}\text { Integrated } \\
\text { Development } \\
\text { I-intellectual; }\end{array}$ & $\begin{array}{l}\text { Understand the issue by } \\
\text { observation }\end{array}$ & Analyse the issue & $\begin{array}{l}\text { Possess Creativity and } \\
\text { imaginative potential } \\
\text { good command over } \\
\text { communication }\end{array}$ & $\begin{array}{l}\text { Able to have Independent Thinking } \\
\text { and intellectual assessment with } \\
\text { good interpretation. }\end{array}$ \\
\hline 4 & $\begin{array}{l}\text { Integrated } \\
\text { Development } \\
\text { S-spiritual }\end{array}$ & $\begin{array}{l}\text { Able to realise GOD and the } \\
\text { spiritual techniques like } \\
\text { chanting mantras, worshiping } \\
\text { GOD }\end{array}$ & $\begin{array}{l}\text { Understand the philosophy of } \\
\text { developing personal relationship } \\
\text { with GOD }\end{array}$ & $\begin{array}{l}\text { Spiritual self-analysis and } \\
\text { able to understand } \\
\text { Introspection }\end{array}$ & $\begin{array}{l}\text { Spiritual techniques and integrating } \\
\text { body, mind and thoughts. }\end{array}$ \\
\hline 5 & $\begin{array}{l}\text { Value } \\
\text { Education }\end{array}$ & $\begin{array}{l}\text { Understand the values of a child } \\
\text { and Himself }\end{array}$ & $\begin{array}{l}\text { Understand the values of the } \\
\text { child and others }\end{array}$ & $\begin{array}{l}\text { Understand the values of the } \\
\text { child and society, Country }\end{array}$ & $\begin{array}{l}\text { Understand the values of the child } \\
\text { and the world and }\end{array}$ \\
\hline 6 & $\begin{array}{l}\text { Value Based } \\
\text { Education }\end{array}$ & $\begin{array}{l}\text { Understand the Values behind } \\
\text { all the cultures through the } \\
\text { cultural celebrations activity. }\end{array}$ & $\begin{array}{l}\text { Understand the value behind the } \\
\text { Community and the culture. }\end{array}$ & $\begin{array}{l}\text { Understand the Value behind } \\
\text { society, community and } \\
\text { culture through seva and } \\
\text { services }\end{array}$ & $\begin{array}{l}\text { Being a good human, and role } \\
\text { model, Able to preserve the ethics } \\
\text { in his field and life. }\end{array}$ \\
\hline 7 & Indian Culture & $\begin{array}{l}\text { Understand the meaning of } \\
\text { culture }\end{array}$ & $\begin{array}{l}\text { Understand the meaning of } \\
\text { customs, and have good } \\
\text { exposure to culture }\end{array}$ & $\begin{array}{l}\text { Have cultural heritage } \\
\text { awareness and appreciation }\end{array}$ & $\begin{array}{l}\text { Have faith and motivation in } \\
\text { culture and ability to explain } \\
\text { culture }\end{array}$ \\
\hline 8 & Patriotism & $\begin{array}{l}\text { Knows about mother country } \\
\text { INDIA and world }\end{array}$ & $\begin{array}{l}\text { Started Loving India by realising } \\
\text { Great INDAINS and resources } \\
\text { namely Human, Brain, 8Natural, } \\
\text { Cultural a9nd spiritual }\end{array}$ & $\begin{array}{l}\text { Believe in INDIA and to } \\
\text { contribute to INDIA's } \\
\text { Development besides } \\
\text { knowing its weakness' }\end{array}$ & $\begin{array}{l}\text { Takes the responsibility of being } \\
\text { an Indian and } \\
\text { Feel proud of an Indian }\end{array}$ \\
\hline 9 & $\begin{array}{l}\text { Universal } \\
\text { Outlook }\end{array}$ & $\begin{array}{l}\text { Understand himself as a citizen } \\
\text { of the World }\end{array}$ & $\begin{array}{l}\text { Understand the harmony in } \\
\text { creation }\end{array}$ & $\begin{array}{l}\text { Understand science and } \\
\text { technology and its growth in } \\
\text { terms of economic wealth }\end{array}$ & $\begin{array}{l}\text { Understand environment and } \\
\text { cosmopolitan geographic regions, } \\
\text { religions and humanity }\end{array}$ \\
\hline 10 & academic & Able to read and write & Able to think and Analyse & Able to apply and adapt & $\begin{array}{l}\text { Have strong skill set Both in life as } \\
\text { well as profession. }\end{array}$ \\
\hline 11 & Curricular & Achieve grades in his subjects & $\begin{array}{l}\text { Achieve grades and understand } \\
\text { his state in assessment category }\end{array}$ & $\begin{array}{l}\text { Understand about education } \\
\text { and outside world prepare } \\
\text { and participate competitive } \\
\text { exams }\end{array}$ & $\begin{array}{l}\text { Able to fix the goal and work hard } \\
\text { to achieve the target. }\end{array}$ \\
\hline 12 & Co-curricular & $\begin{array}{l}\text { Develop the Skill to Participate } \\
\text { to give the best outcome in the } \\
\text { co-curricular activities inside } \\
\text { classroom }\end{array}$ & $\begin{array}{l}\text { Develop the personality to have } \\
\text { the potential strength in } \\
\text { attending co-curricular activity } \\
\text { inside and outside classroom }\end{array}$ & $\begin{array}{l}\text { Able to think and develop } \\
\text { his self interest in the co- } \\
\text { curricular activity inside and } \\
\text { outside classroom and school }\end{array}$ & $\begin{array}{l}\text { Has leadership qualities like co- } \\
\text { operate, co-ordinate and organize } \\
\text { the challenging task and move to } \\
\text { the next technologically very fast } \\
\text { moving world. }\end{array}$ \\
\hline 13 & $\begin{array}{l}\text { Extra- } \\
\text { curricular }\end{array}$ & $\begin{array}{l}\text { They lead themselves in } \\
\text { developing their full potential in } \\
\text { extracurricular activities (kids } \\
\text { club) apply it in their life. }\end{array}$ & $\begin{array}{l}\text { They lead themselves in } \\
\text { developing their full potential in } \\
\text { extracurricular activities (science } \\
\text { and technology) and apply it in } \\
\text { their life. }\end{array}$ & $\begin{array}{l}\text { They lead themselves in } \\
\text { developing their full } \\
\text { potential in extracurricular } \\
\text { activities. (multidisciplinary } \\
\text { field) and apply it in their } \\
\text { life. }\end{array}$ & $\begin{array}{l}\text { They lead themselves in } \\
\text { developing their full potential in } \\
\text { extracurricular activities (converge } \\
\text { to their own specific field) and } \\
\text { apply it in their life. }\end{array}$ \\
\hline 14 & cultural & $\begin{array}{l}\text { Understand the soft skills } \\
\text { needed to participate in cultural } \\
\text { activities }\end{array}$ & $\begin{array}{l}\text { Able to organize committees for } \\
\text { various cultural events }\end{array}$ & $\begin{array}{l}\text { Have skill to learn knew } \\
\text { languages and value others } \\
\text { custom and culture }\end{array}$ & $\begin{array}{l}\text { Being a volunteer in participating } \\
\text { social cultural activities and } \\
\text { nurtured as a good Human. }\end{array}$ \\
\hline 15. & Digital Society & $\begin{array}{l}\text { Have the knowledge of social } \\
\text { media, whatsapp for education } \\
\text { Listening/speaking/reading. }\end{array}$ & $\begin{array}{l}\text { Have the knowledge of social } \\
\text { media, whatsapp for education } \\
\text { LSRW }\end{array}$ & $\begin{array}{l}\text { Able to share and use android } \\
\text { apps }\end{array}$ & Able to create blogs and apps \\
\hline 16 & $\begin{array}{l}\text { Digital } \\
\text { Parenting }\end{array}$ & $\begin{array}{l}\text { Have many issues facing in using } \\
\text { different apps to discuss with } \\
\text { parents }\end{array}$ & $\begin{array}{l}\text { Psychologically having fear about } \\
\text { issues and to consult parents. }\end{array}$ & $\begin{array}{l}\text { They started trusting friends } \\
\text { for solving issues }\end{array}$ & $\begin{array}{l}\text { Able to know about syber crime and } \\
\text { can approach cycber experts to deal } \\
\text { with issues }\end{array}$ \\
\hline 17 & $\begin{array}{l}\text { Heart- } \\
\text { Transformation }\end{array}$ & $\begin{array}{l}\text { Psychologically trying to prepare } \\
\text { for realsing the digital influence }\end{array}$ & $\begin{array}{l}\text { Able to analyse problems } \\
\text { psychologically }\end{array}$ & Able to solve problems & $\begin{array}{l}\text { Able to give value based solutions } \\
\text { to other problems }\end{array}$ \\
\hline 18 & $\begin{array}{l}\text { Intellectual } \\
\text { Transformation }\end{array}$ & $\begin{array}{l}\text { Started believing what is } \\
\text { available in Digital Media }\end{array}$ & $\begin{array}{l}\text { Able to justify intellect with } \\
\text { evidence }\end{array}$ & $\begin{array}{l}\text { Able to maintain evidence for } \\
\text { their intellect }\end{array}$ & Able to create or destroy evidence \\
\hline 19 & $\begin{array}{l}\text { Social } \\
\text { Distancing }\end{array}$ & Lack of thinking and creativity & Unable to understand others need & $\begin{array}{l}\text { Reluctant to respond to others } \\
\text { need }\end{array}$ & $\begin{array}{l}\text { Hard to change to social } \\
\text { connectivity in real. }\end{array}$ \\
\hline 20 & Socio Economic & Know about money & $\begin{array}{l}\text { Know about transaction through } \\
\text { smart phone }\end{array}$ & $\begin{array}{l}\text { Have interest to start own } \\
\text { business }\end{array}$ & To become an entrepreneur \\
\hline
\end{tabular}




\begin{tabular}{|c|c|c|c|}
\hline SL_NO & Parameter & School Education & Special Education \\
\hline 1 & Teaching Style & $\begin{array}{l}\text { Nosingle specified strle is } \\
\text { encouraged. }\end{array}$ & Student Specific \\
\hline 2 & Teachingaids & $\begin{array}{l}\text { Noconmon taching aid is } \\
\text { suggested }\end{array}$ & Student Specific \\
\hline 3 & Assessment & $\begin{array}{l}\text { Corem on stendard assessment } \\
\text { Pattern is prescribed by } \\
\text { board,ag } \\
\text { CBSE,ST ATEB.ARDICSE } \\
\text { ETC. }\end{array}$ & $\begin{array}{l}\text { No Common standard assessment Pattem is } \\
\text { prescribed by board sofar eg } \\
\text { CBSE,ST ATEB.ARDICSE EIC. }\end{array}$ \\
\hline 4 & Time period & $\begin{array}{l}\text { Prescribed time period is } \\
\text { specifiad. }\end{array}$ & NoPrescribed time period \\
\hline 5 & Goals & $\begin{array}{l}\text { Is based } \infty \text { academics, maths } \\
\text { and science }\end{array}$ & $\begin{array}{l}\text { Is not based on Acadernics but on Daily } \\
\text { functioning and vocational }\end{array}$ \\
\hline 6 & classes & Age wise clases an defined & $\begin{array}{l}\text { The Nental haalth has significant impact in } \\
\text { fixing the class. }\end{array}$ \\
\hline 7 & Class sizs & $25-30$ students per teacher & 5 gives better cutcome but the size waybe 20 \\
\hline 8 & Opportunity & $\begin{array}{l}\text { The opporturities are } \\
\text { chatlenging }\end{array}$ & The oppor tnitie sare thratening \\
\hline 9 & Life span & Between $70-80$ for halt'y & $\begin{array}{l}\text { Between } 50-60 \text { for heal thy life with proper } \\
\text { medication }\end{array}$ \\
\hline 10 & Community & $\begin{array}{l}\text { They are easilyadapt to the } \\
\text { community }\end{array}$ & Conmunityadaptation is chatlenging \\
\hline 11. & Life style & $\begin{array}{l}\text { They can live as like as every } \\
\text { other standerd life of human } \\
\text { being }\end{array}$ & Different and equatlystandard \\
\hline 12 & Paraprcfessional & Strictlynot required & Required for netter outcome \\
\hline 13 & Parents approach & Happy and proud & Felt arsed and unhappy \\
\hline 14 & $\begin{array}{l}\text { Tecmology } \\
\text { iffluence }\end{array}$ & Verymuch & Comparatively low \\
\hline 15 & Cost of living & Comparatively less expensive & Highlyexpensive \\
\hline 16 & After schooling & $\begin{array}{l}\text { Individual transfomation } \\
\text { happened and able to take } \\
\text { charge his own life }\end{array}$ & $\begin{array}{l}\text { Lies in the hands of the special edvcator } \\
\text { oherwise they becone bor den to thenselves }\end{array}$ \\
\hline 17 & Instruction & Coerm on rules can be appliad & individualized plans of instruction is applicable \\
\hline 18 & objective & $\begin{array}{l}\text { Totransform the student into } \\
\text { self sufficient andMan of } \\
\text { Vision }\end{array}$ & 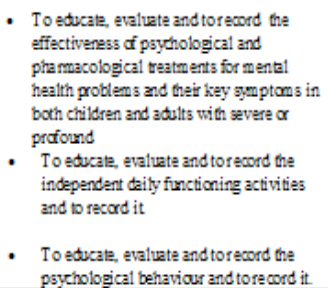 \\
\hline
\end{tabular}

Table 2: DOSE

\begin{tabular}{|c|c|c|c|}
\hline SI.NO & Para meter & School Education & Special Educ ation \\
\hline 19 & $\begin{array}{l}\text { Psychological } \\
\text { interventions }\end{array}$ & $\begin{array}{l}\text { Once in a year the } \\
\text { dental, eye camp is } \\
\text { or ganised to record } \\
\text { the health status of a } \\
\text { student }\end{array}$ & $\begin{array}{l}\text { Eligible psych ological interventions } \\
\text { were delivered by a trained lay } \\
\text { therapist or qualified professional who } \\
\text { sysematically applied interventions } \\
\text { based on well-established } \\
\text { psychological principles and } \\
\text { techniques directly to the person with } \\
\text { an intellectual disability, either } \\
\text { individually or in a group }\end{array}$ \\
\hline 20 & \begin{tabular}{l|} 
Pharmacolog ical \\
interventions
\end{tabular} & $\begin{array}{l}\text { On sch } \infty 1 \text { days the, } \\
\text { sch } \infty \text { doctor advises } \\
\text { the clinical advised } \\
\text { and the student is } \\
\text { taken care by the } \\
\text { parent }\end{array}$ & $\begin{array}{l}\text { F } \propto \text { phamacological interventions, it } \\
\text { was expected that the pharmaceutical } \\
\text { agent was given with regular review } \\
\text { by a qualified madical practitioner or } \\
\text { health professional, and recognised at } \\
\text { least in principle as a potential } \\
\text { treatment for a mental health } \\
\text { problem/symptom. }\end{array}$ \\
\hline 21 & $\begin{array}{l}\text { psychiatic } \\
\text { diagnosis }\end{array}$ & Not required & Strictly advised \\
\hline 22 & $\begin{array}{l}\text { Resources and } \\
\text { services }\end{array}$ & Plenty & Very poor and in nural areas \\
\hline 23 & $\begin{array}{l}\text { Job readiness } \\
\text { skills }\end{array}$ & Acquired & Acquired \\
\hline 24 & Family & $\begin{array}{l}\text { Family Assistance is } \\
\text { great }\end{array}$ & $\begin{array}{l}\text { Nowadays the special children are } \\
\text { ne glected }\end{array}$ \\
\hline 25 & employment & Open competition & Different stages of implementation \\
\hline 26. & $\begin{array}{l}\text { Unemployment } \\
\text { allowance }\end{array}$ & Open & Different stages of implementation \\
\hline 27 & $\begin{array}{l}\text { special Insurance } \\
\text { scheme }\end{array}$ & Open & Different stages of implementation \\
\hline 28 & $\begin{array}{l}\text { Creation of } \\
\text { Barrier-free } \\
\text { environments }\end{array}$ & open & Different stages of implementation \\
\hline 29 & $\begin{array}{l}\text { Medical } \\
\text { allowance }\end{array}$ & Not required & Strictly required \\
\hline 30 & Physical therapy & \begin{tabular}{l|} 
Only games period \\
included in time table
\end{tabular} & Physical therapy is included \\
\hline 31 & Curriculum & $\begin{array}{l}\text { Cultural, co- } \\
\text { curricular, } \\
\text { extracurricular, } \\
\text { academics }\end{array}$ & $\begin{array}{l}\text { Functional ma thematics and reading } \\
\text { and writing. }\end{array}$ \\
\hline 32 & Transition & $\begin{array}{l}\text { It is gradual and } \\
\text { student undergo } \\
\text { hormonal unbiased. }\end{array}$ & $\begin{array}{l}\text { Transition marks a time where an } \\
\text { individual ga ins greater chcice and }\end{array}$ \\
\hline
\end{tabular}

Table 3: DOSE

DOSE $^{*}$-Desired outcome on Special Education

8. To give clinical recommendations on Vision, hearing, understanding, moving, communicating and general behaviour.

9. The Preventive measures namely, Prevent abuse, Prevent separation, Reunite families, Provide alternative care, Leave no one behind are the main outcome parameter on every stage of DOSE.

10. The Transition from one stage to another stage depends on the up-to-date performental measuring scale. For example, The behavioural assessment scale for Indian children with mental retardation (BASIC-
MR) was used to quantify the study subjects' behavioural problems before and after we applied behavioural management techniques (baseline and post-intervention, respectively).

11. To provide conflict resolution guidelines and dispute resolution to the parents whenever required immediately for smooth functioning of the special education.

12. To inspire the adolescent CWSN, the successful and famous personalities with disabilities can be invited to give motivational talk to the adult from age 16 upwards. 
13. The ad hoc, confused and uncoordinated lack of easily accessible information for parents and young people about what future possibilities in the current transition services can be avoided by using the proposed model.

14. To provide resources for individuals with intellectual disabilities and their carers to access advice about body changes and maturation during the transition to adulthood.

15. To prepare lesson plans, activities, report, assessment, evaluation for student specific CWSN.

The DOSE is translated into a set of developmental outcomes for each key stage of our special education system. The Key Stage Outcomes spell out what the special Education Service aspires to develop in our students through:

1. Early intervention (birth -2 years old).

2. Early head start (birth to 2).

3. Head start (3 to 5).

4. Early childhood intervention( 3 to 5 years old).

5. Kindergarten to secondary education(6 to 16 years old).

6. Transition planning for adult hoods(14-6 years old).

7. Transition into secondary education 16 to 21 years of age.

8. Transition services to the adult life.

9. Transition with the development of sexual maturity.

Each educational level builds upon the previous stages and lays the foundation for subsequent ones.

Analysis of the Key Stage of special education Outcomes. There are thirty-one outcomes at each key stage. Taken together, the Key Stage Outcomes make explicit what we aspire to develop in our young so as to lay the strong foundations for them to thrive and achieve success in life as contributing members of society.

$\square$ The Special Educator, along with the prescribed outcome by clinical psychologists, can apply the normal children's (as per Physiological age) outcome to assess the outcome of the individual
CWSN to promote from one stage to another stage or to reschedule the process for getting the aimed transformation.

The Academics, Vocational or Job kill training, can be included thorugh the transition period for CWSN KIDS (16-23)

Developing a broader education system and with educators who have specialized training is an urgent requirement. Learning should be a fun and an adventurous activity for both children with and without special needs. This proposed KLMN SWASTIK MODEL ensures the involvement and commitment of parents, doctors, peer group and the society, government for the upliftment of special education.

\section{CONCLUSION}

The Indian government has demonstrated its determination by implementing a number of policies, programs, and legislations for inclusion in the last four decades; while on the other it faces a number of unique challenges that limits its successful implementation. Policy makers need to address these challenges appropriately to make inclusive education a reality for millions of children with disabilities in India. Special Education should therefore focus on designing a structure of education that can overpower the disadvantages related to these disabilities, and help children in getting quality education. This Research article aims at helping to meet the unique socio-culturaleducational traditions of India ${ }^{[18]}$.

\section{ACKNOWLEDGEMENTS}

The Author proposes her sincere thanks to Smt. Mini Jackson, Principal Chinmayavidyalaya mat.hr.sec. school, Vadavalli, Coimbatore and to Dr. T. Dorairaj, Director, Indira Gandhi college of Special Education, Kanuvai, Coimbatore. The author records her thanks to the resources that gave motivational strength to write the article. The author wishes to record her wholehearted thanks and acknowledgement for all the information providers that brings change in her thoughts.

\section{REFERENCES}

1. Kumar Sanjeev at el. "Inclusive Education In India", Electronic Journal of Inclusive Education, volume 2 number 2 (Summer/fall 2007) article 7, https:// 
corescholar.libraries.wright.edu/cgi/viewcontent. cgi? article $=1086 \&$ context $=$ ejie.

2. https://corescholar.libraries.wright.edu/cgi/viewcontent. cgi? article $=1086 \&$ context $=$ ejie

3. https://internationalteacherstraining.com/blog/ importance-special-education-children-special-needs/

4. https://www.thebetterindia.com/16449/famousindians-with-disability/?utm_source=pofod\&utm_ medium=Medium

5. "The Hindu Joint".

6. https://www.thehindubusinessline.com/opinion/ why-the-indian-family-is-a-great-institution-ep/ article23884420.ece

7. https://www.incometaxindia.gov.in/Pages/i-am/huf. aspx?k=Introduction\#

8. Govindu Sri Rama Murthi. Span of Life. Ranga Printers. p. 5 .

9. Prasna Marga Part-2. New Delhi: Motilal Banarsidass Publishers, pp. 283.

10. https://thepatriot.com.na/index.php/2016/05/06/ traditional-vs-modern-motherhood/
11. https://www.ncbi.nlm.nih.gov/pmc/articles/PMC3927244/

12. Special Ed: Modification for Students with Intellectual Disabilities by brighthubeducation.org)

13. ]https://therapytravelers.com/strategies-teachingstudents-intellectual-disabilities/

14. Shantha Rau Barriga et al. 2017. "Children with disabilities: Deprivation of liberty in the name of care and treatment", Protecting Children Against Torture in Detention: Global Solutions, March 7, 2017.

15. https://ijip.in/articles/a-klmn-swastik-model-for-allround-development-of-students-based-on-educationalpsychology/

16. https://www.ncbi.nlm.nih.gov/pmc/articles/PMC3299352/

17. Dr. J. Komalalakshmi, 2017. “A design and analysis of Chinmaya vision programme on outcome based education", International Journal of Information Research and Review, 04(12): 4948-4951.

18. file://E:/specialeducation/special $\% 20$ education $\% 20 \mathrm{in} \% 20$ ndia\%20research\%20gate.pdf 